\title{
CLASSROOM ETHNOGRAPHY: ADAPT OR ADOPT?
}

\author{
Amnah Abdullah ${ }^{1}$ \\ Faculty of Psychology and Education, University Malaysia Sabah (UMS), Malaysia. \\ (Email: amnah.abdullah88@gmail.com) \\ Mohd. Zaki Ishak ${ }^{2}$ \\ Faculty of Psychology and Education, University Malaysia Sabah (UMS), Malaysia. \\ (Email: movolk@ums.edu.my) \\ Robert Francis Peters ${ }^{3}$ \\ Institute for Tropical Biology and Conservation, University Malaysia Sabah (UMS), Malaysia. \\ (Email: rfpeters@ums.edu.my)

\section{Aisah Kasan ${ }^{4}$} \\ Toh Puan Hajjah Rahmah Islamic Religious Secondary School, Sabah, Malaysia. \\ (Email: amnah.abdullah88@gmail.com)
}

Received date: 03-09-2019

Revised date: 15-09-2019

Accepted date: 03-10-2019

Published date: 05-12-2019

To cite this document: Abdullah, A., Ishak, M. Z., Peters, R. F., \& Kasan, A. (2019). Classroom Ethnography: Adapt or Adopt? International Journal of Humanities, Philosophy and Language, 2(8), 15-27.

DOI: $10.35631 /$ ijhpl.28002

\begin{abstract}
Ethnography, in general, is a methodology that has been well known to many as conducted to study a culture-sharing group that could provide an understanding of a larger issue. However, ethnographic research in an educational setting is defined as research on and in educational institutions based on participant observation and/or permanent recordings of everyday life in naturally occurring settings. Then again, classroom ethnography who possess a family resemblance to ethnography is not well understood to many qualitative researchers in this region. Its value in the body of knowledge is not well understood also. In order to appreciate the value of this methodology, the history and development of this research with relation to science education could better enlighten the research community of its value and appropriateness in this region rich in its diverse culture and ethnicity. Different scholars have different scope and perspectives in understanding ethnography. The aim of this article is to open up new research directions in research methodologies for potential local postgraduates.
\end{abstract}

Keywords: Ethnography, Classroom Ethnography, Qualitative Research, Science, STS

\section{Introduction}

There is a growing interest in qualitative research in general and perhaps ethnography in particular. However, its history and its diverse application in educational setting such as science education might not be well understood. To give insight into the potential of ethnography, which has certainly a great deal to offer to the body of knowledge, our starting point in this 
discourse of ethnography in general and classroom ethnography in particularly is through two great groups of scholars. The American base Yvonna S. Lincoln and Norman K. Denzin, and the British base Sara Delamont and Paul Atkinson (1980). Essentially, two books were used in this discourse. The Handbook of Ethnography (Atkinson et al., 2001) and The Handbook of Qualitative Research (Denzin \& Lincoln, 1994).

\section{Qualitative Educational Research}

There are five points that will be discussed in this literature review: the broad definition of ethnography, ethnography in qualitative research, the discourse of two great groups of scholars, and some points of weaknesses and strengths of ethnographic study. These points lead towards the necessity of a shift and the importance of classroom ethnography in the following sections.

Ethnography's value and contribution in the body of knowledge has been invaluable in the arena of qualitative research, and there are two (2) strands of thoughts in particular cultural anthropology and sociology originating namely from Denzin and Lincoln (1994) and Delamont and Atkinson (1980). Their perspectives are explicit in their books where one is "a general handbook of qualitative research methods" (Delamont \& Atkinson, 2001: 5) while the other is ethnography per se, respectively. It should be pointed out their bifurcating points and tie the consecutive discourse down to classroom ethnography and science education.

Denzin and Lincoln (1994) believed that the future of ethnography could be speculated by using the idea of the "moments" model in the development of ethnographic research. However, Delamont and Atkinson (1980) do not agree with what they call Denzin's and Lincoln's "linear view of development" (Atkinson et al., 2001: 3) of ethnographic research. Atkinson et al. (2001) disagree that ethnography's history could be tidied up into moments but rather an acceptance that ethnography whether in sociology or anthropology - is an entity that can never be stable. Denzin and Lincoln (2000) believed that ethnography (one of the research strategies) could be bounded by their suggested list of theoretical paradigms. However, Atkinson et al. (2001: 4) believed when studying culture, there would always be "repeated tension between the nomothetic search for law-like regularities, and the idiographic interpretation of cultures". Much recently though, Denzin and Lincoln (2018) is of the opinion that moments may crosscut and overlap and coexist in the present. Nonetheless, "[e]thnographic research remains firmly rooted in the first-hand exploration of research settings" (Atkinson et al. 2001: 5), and it must be committed to "the interpretation of local and situated cultures" (Atkinson et al. 2001: 6). It also means that ethnography does not always mean exactly the same thing "to all social scientists at all times or under all circumstances" (Atkinson et al. 2001: 5). Moreover, the global conduct of ethnography merits sharing and contributing to the global body of knowledge from an international array of authors, including cross-disciplinary ones, and should not be confined to Anglophone international community (Atkinson et al. 2001).

\section{Definition}

As a broad definition, ethnography is the systematic study of people and cultures. It is conducted to study a culture-sharing group that could provide an understanding of a larger issue (Creswell, 2015). Ethnographic study requires "the researcher as a major instrument of research" (Gordon et al., 2001: 188). Gordon et al. (2001) further wrote that the research methods used are mostly qualitative but it can also be quantitative. In educational setting, ethnographic research is defined as "research on and in educational institutions based on participant observation and/or permanent recordings of everyday life in naturally occurring settings" (Delamont \& Atkinson, 1995: 15). However, in presenting the interdisciplinary field 
STS (STS, Science and Technology Studies), it is remarked that the term 'ethnography' could vary in meaning across the disciplines (Hess, 2001).

\section{The Research Process}

In general, the conduct of qualitative educational research is possible through well-known approaches or research strategies. For Creswell and Poth (2018), there are five approaches to qualitative research: narrative research, phenomenology, grounded theory, ethnography, and case study. For Denzin and Lincoln (2000), their research strategies were broader: study design, case study, ethnography, phenomenology, grounded theory, life history, historical method, action and applied research, and clinical research. Moreover, researchers felt other elements should be specified in order to maintain the quality of a research. The emphasis on the theoretical paradigms should not be neglected. Thus the research approaches or strategies must be bounded by the research philosophy as illustrated in Figure 1.

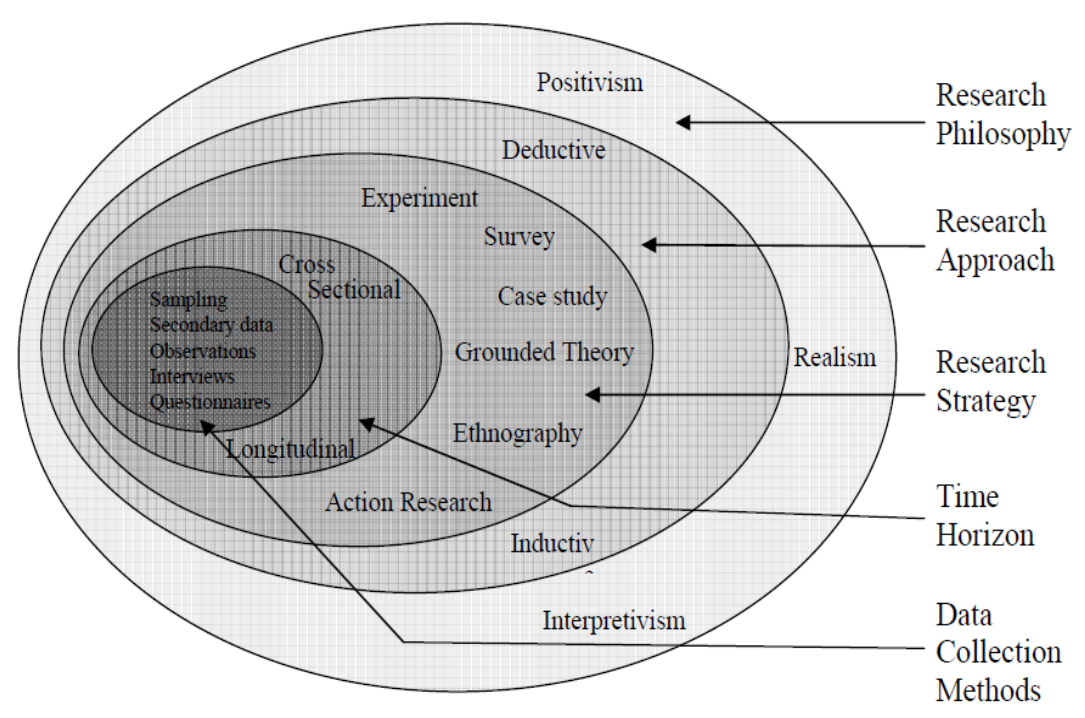

Figure 1: The Research Process 'Onion'

Source: Saunders et al. in Kulatunga et al. (2007)

The explanation of the research philosophy is compatible and well elaborated in Denzin and Lincoln (2000). Conclusively, in order to conduct a quality research the research process should be discussed a priori right down to the methods appropriate to each theoretical paradigm. The development of ethnography in science education is not well understood in this part of the region. Even more, in America and Britain, the popularity of educational ethnography debuted in the 1970's. It slowly caught momentum in Canada, Australia, and other European countries by the 1990's. However, Gordon et al. (2001) lamented on the limited exchange of knowledge in non-Anglophone European countries due to language gap. From Gordon et al.'s (2001) study, much focus was on 7 to 16 year old students from ordinary classes in state schools. Gordon et al. (2001) added that much of the interpretation of the lives of children was done from adult perspectives. The application of ethnography in general and classroom ethnography in particular merits discourse of its history and development. This article focuses on ethnography as a classroom research strategy.

\section{Ethnography}

In the literature, ethnography "refers to a social scientific description of a people and the cultural basis of their peoplehood (Peacock, 1986)" (Vidich \& Lyman, 2000: 40). 
"Ethnography is thought to be a theoretical, to be concerned solely with description. However, the observations of the ethnographer are always guided by world images that determine which data are salient and which are not: An act of attention to one rather than another object reveals one dimension of the observer's value commitment, as well as his or her value-laden interests" (Vidich \& Lyman, 2000: 40). However, “[d]uring the 1960's and 1970's, there was a more pointed critique and analysis of ethnography, a reflexive turn in qualitative research. One meaning of reflexivity is that the scientific observer is part and parcel of the setting, context, and culture he or she is trying to understand and represent" (Altheide \& Johnson, 1998: 285). It is after this reflexive turn that more and more qualitative researchers valued the meaning of validity in ethnography or qualitative research for that matter (Altheide \& Johnson, 1998).

In the march of time, ethnography naturally developed from research in far off foreign exotic locations to closer to home ethnography (Vidich \& Lyman, 2000). By the 1980's educational ethnography surfaced and it was "based on participant observation and/or permanent recordings of everyday life in naturally occurring settings" (Delamont \& Atkinson, 1980: 139). The settings were educational settings.

For Delamont and Atkinson (1980), there are two traditions of ethnography in history. In the 1980's, much of educational ethnography was done in Britain and America. Interestingly, ethnographic research done in schools in Britain and the United States were not aware of each other's work. According to Delamont and Atkinson (1980), despite both countries "common approach to the conduct of inquiry there seems to be little in the way of shared interests or theoretical perspectives" (Delamont \& Atkinson, 1980: 140). Hence, a sign of their "different styles of the respective traditions - their characteristic concerns, substantive, methodological and theoretical" (Delamont \& Atkinson, 1980: 143).

The differences mentioned by Delamont and Atkinson (1980) are summarized in Table 1:

Table 1: British and American School Ethnography Differed

\begin{tabular}{|c|c|c|}
\hline Research & Britain & America and Canada \\
\hline Conducted by & $\begin{array}{l}\text { Researchers although had } \\
\text { backgrounds in anthropology } \\
\text { but their work had stronger } \\
\text { sociological orientation. }\end{array}$ & Applied anthropologists. \\
\hline $\begin{array}{l}\text { Claims school } \\
\text { and classroom } \\
\text { ethnography are }\end{array}$ & $\begin{array}{l}\text { Predominantly } \\
\text { sociological in } \\
\text { orientation. }\end{array}$ & $\begin{array}{l}\text { Predominantly } \\
\text { anthropological in } \\
\text { orientation. }\end{array}$ \\
\hline Focus & $\begin{array}{l}\text { On "social class and } \\
\text { structures that constrain } \\
\text { both teachers and pupils" } \\
\text { (Gordon et al., 2001: 188). }\end{array}$ & $\begin{array}{l}\text { "on ethnic differences } \\
\text { in classrooms, where } \\
\text { teachers are agents of } \\
\text { cultural imposition" } \\
\text { (Gordon et al., 2001: } \\
\text { 188). }\end{array}$ \\
\hline $\begin{array}{l}\text { Research concerns } \\
\text { according to Burnett } \\
\text { (1974) in Delamont and } \\
\text { Atkinson (1980: 143) }\end{array}$ & $\begin{array}{l}\text { Few work on educational } \\
\text { experiences and problems } \\
\text { in Britain's different } \\
\text { minority ethnic groups. }\end{array}$ & $\begin{array}{l}\text { Ethnic group. } \\
\text { 'Research attention } \\
\text { concentrated on } \\
\text { 'problem' groups in }\end{array}$ \\
\hline
\end{tabular}




According to
Delamont and
Atkinson (1980:
145)
Research concerns
according to
Delamont and
Atkinson (1980:
146)

Openness in research

Connection

Common neglect
No significant British work on the ethnography of rural schooling.

Preoccupation with social class.

Emphasising the structural-functional or structuralist modes of analysis.

Little attention to issues of education and socialisation (except in so far as they are implied in issues of kinship and marriage, rituals of the life-cycle, descent and inheritance and so on).

Less accommodating and

"It seems to be 'women's work'." (Delamont \& Atkinson, 1980: 146)

Negative connection:

The label applied anthropologists was avoided due to its 'assumed' low status, due to its 'assumed' lack of theoretical underpinnings

Gender as an organising theme. educational terms, because they are seen to be "failing" " (Delamont \& Atkinson, 1980: 143). Significant American investigation of rural schools in the context of its rural 'community' setting.

Preoccupation with race and culture.

Issues of cultural variations and 'culture clash'.

Celebrate the cultural uniqueness of the researcher's chosen setting or

Stress the 'clash' between that culture and that of the school.

American tradition of cultural anthropology always accepted considerable influence from other social sciences (e.g. the sub-discipline of 'culture and personality' studies - committed to the investigation of socialisation and enculturation)

Positive Connection

Gender as an organising theme. 


\begin{tabular}{|c|c|c|}
\hline $\begin{array}{l}\text { Researchers } \\
\text { awareness }\end{array}$ & $\begin{array}{l}\text { More theoretical } \\
\text { and methodological } \\
\text { self-awareness. }\end{array}$ & $\begin{array}{l}\text { With reference to } \\
\text { Burnett (1974) in } \\
\text { Delamont and Atkinson } \\
\text { (1980: 147), the } \\
\text { research methods } \\
\text { employed were } \\
\text { extremely idiographic. }\end{array}$ \\
\hline $\begin{array}{l}\text { Conclusion } \\
\text { (Delamont \& Atkinson, } \\
\text { 1980: 146) }\end{array}$ & $\begin{array}{l}\text { Underdeveloped speciality. } \\
\text { Thus scholars (local } \\
\text { and foreign) trained } \\
\text { in this field would be } \\
\text { predominantly sociological } \\
\text { in orientation. They are } \\
\text { less accommodating } \\
\text { and prefers research } \\
\text { confined to their } \\
\text { 'pure' discipline. }\end{array}$ & $\begin{array}{l}\text { Accepted speciality. } \\
\text { American anthropologists } \\
\text { can study education } \\
\text { without appearing to } \\
\text { abandon the confines } \\
\text { of their 'pure' discipline. }\end{array}$ \\
\hline $\begin{array}{l}\text { Incorporated approach } \\
\text { (Delamont \& Atkinson, } \\
\text { 1980; Gordon et } \\
\text { al. 2001) }\end{array}$ & $\begin{array}{l}\text { The anti-positivistic and } \\
\text { 'interpretative' approach } \\
\text { incorporated into } \\
\text { the British sociology } \\
\text { of education are: } \\
\text { symbolic interactionism, } \\
\text { phenomenology, } \\
\text { ethnomethodology. }\end{array}$ & A broader approach. \\
\hline
\end{tabular}

Source: Delamont and Atkinson (1980)

A closer look on the research concerns by continents, according to Burnett (1974) in Delamont and Atkinson (1980: 143):

-Percentage of published work were 36\% Africa, 22\% Asia, 17\% Pacific Islands and Australasia

-African studies covered Egypt to the Cape, and Liberia to Tanzania, however studies are only done by one or two researchers.

-Asian studies covered Japan, India, Thailand and China.

-Pacific Islands and Australasia covered Hawaii, Guam and the Philippines and not ex-British or French colonies.

Gordon et al. (2001) even stressed how differently the British (Louis M. Smith) and American (Martyn Hammersley) have been doing classroom ethnography a few decades back.

Of these two different traditions mentioned earlier, there exist an exception. It is important to mention here that " $\mathrm{t}]$ he small numbers of American and Canadian school ethnographers who see themselves as sociologists actually look to Britain to find inspiration and an audience for their work" (Delamont and Atkinson, 1980: 141) and vices versa. Hence, the exception of a British scholar (e.g. Driver, 1979) who is of interest in this ensuing study. According to Delamont and Atkinson (1980), Rosalind Driver is one of the very few British researcher at that time who conducted research with a predominantly anthropological orientation. 
When anthropologist George Spindler (Gordon et al., 2001), started fieldwork in schools in the 1950, the essence of his work was to make the strange familiar. However, it was difficult to see the strangeness in the school setting because we all have had at one point in our lives prior experience in similar setting (Erickson, 2010). Therefore, making the familiar strange was the core task of a school ethnographer (Gordon et al., 2001). Indeed, much different from traditional ethnography where the essence of the ethnographer's work was in making the strange familiar (Erickson, 2010).

When science and technology took momentum, ethnography in the science and technology setting (Hess, 2001) made its debut around the 1980's. According to Hess (2001), in the STS field, two generations of ethnographic researchers dominated the field.

The first generation of STS ethnographers, during the early 1980's, were both Europeans and non-Europeans (mostly Americans). This is the STS British-dominated period. It is a time when STS was known as the sociology of scientific knowledge (SSK, sociology of scientific knowledge). The social construction of knowledge was the central research concept for SSK (Hess, 2001). Hess (2001: 234) explained that "the problem of how decisions about the credibility of knowledge claims and methods involve a mix of social and technical factors" sometimes known as 'laboratory studies'. It is a period where observations were the accepted facts, through the process of persuasion (Hess, 2001). However, when science turned to technology, the central research concept for SSK became co-construction replacing the term social construction. The research methods thus were more on documentary sources and interviews instead of fieldwork (Hess, 2001).

In conclusion, Hess (2001) postulated the construction problem focused on how social and technical factors are interwoven in knowledge and technology production (thus social construction), or how sociotechnical networks and societies are mutually constituted (coconstruction). Hence ethnographers viewed the knowledge-culture relationship as either-or. Most of the researches were mono-sited and it took a shorter period of research.

The second generation of STS ethnographers were more American and "oriented toward social problems (environmental, class, race, sex, sexuality, and colonial) in addition to theoretical problems in the sociology and philosophy of knowledge" (Hess, 2001: 236). There were no more 'laboratory studies' as these ethnographers had a wider field site. The knowledge experts were also more diverse as lay groups, activists, social movements, the media and popular culture viewpoints were examined.

In conclusion, Hess (2001) postulated the construction problem focused on how cultural meanings or legitimating power relations are embedded in science and technology (cultural and political constructions) and how different actors interpret science and technology (reconstruction). Hence ethnographers viewed the knowledge-culture relationship as both, instead of the either-or relationship of the first generation. Most of the researches were multisited and it took a longer period of research (Hess, 2001).

With the earlier explanations on the first and second generations, it is clear then that unlike traditional ethnography of a lone ethnographer wondering into a remote village, in the ethnography of science and technology fieldwork sites are not remote. The ethnography of science and technology fieldwork is connected with the world system, and is often part of the ethnographer's own society. In addition, unlike the traditional ethnographer as a naïve student 
learning the culture from the informants or teacher, ethnographer and informants are groping together to understand what is going on. This situation permits the possibility of informants employing ethnographers and thus the possibility of the informants controlling what the ethnographer can and cannot report (Hess, 2001).

\section{Limitations and Strengths}

Some limitations of ethnographic study are as follows. The findings in this ethnographic study are not designed to generalize to a population. It is not a cause-effect relationship. Thus an ethnographic study has to be described as detailed as possible to allow transferability. Most often an ethnographic study trys to "discover the relationship between culture and behavior" and not to "locate causality between variables" (Gray, 2013: 22). Its unit of analysis are events and not operationalizing concepts so that they can be measured (Gray, 2013). After description and analysis, interpretation in ethnographic study "is the most subjective" (Creswell, 2015: 473). Furthermore, the "fieldnotes are not a closed, completed, final text: rather they are indeterminate, subject to reading, rereading, coding, recording, interpreting, reinterpreting" (Atkinson et al., 2001: 3). Therefore, "Revisiting, or reopening, of ethnographers' accounts and analyses of their fieldwork" are encouraged. Due to the subjectivity of this ethnographic research, some may agree with the study and some not. Atkinson et al. (2001: 4) emphasized "the extent to which ethnography in sociology or anthropology - whether conceived in terms of method or its textual products - has never been a stable entity", there is "a repeated tension between the nomothetic search for law-like regularities, and the idiographic interpretation of cultures".

It is also crucial to understand limitations when discussing about analyzing and interpreting quantitative data vis a vis qualitative data. "Limitations are potential weaknesses or problems with the study identified by the researcher...they often relate to inadequate measures of variables, loss or lack of participants, small sample sizes, errors in measurement, and other factors typically related to data collection and analysis." (Creswell, 2015: 199). The goal of limitations in quantitative research is to "judge to what extent the findings can or cannot be generalized to other people and situations" (Creswell, 2015: 199). However, in qualitative research these "limitations may address problems in data collection, unanswered questions by participants, or better selection of purposeful sampling of individuals or sites for the study" (Creswell, 2015: 259). In other words, limitations in quantitative research relate to the instrument used, limitations in qualitative research relate to the researcher as instrument (O’Reilly, 2009) thus human in nature.

Some strengths of ethnographic study are as follows. Ethnography is committed to the "firsthand experience and exploration of a particular social or cultural setting on the basis of (though not exclusively by) participant observation" (Atkinson et al., 2001: 4). Moreover, besides being contextual and situated, there is a variety of perspectives in ethnographic research (Atkinson et al., 2001). Hence, the global contribution of ethnographic study from different continents from an international array of authors, but also cross-disciplinary one are welcomed (Atkinson et al., 2001). The number of steps for ethnographic data analysis are fewer. Creswell and Poth (2017: 104) wrote "At the data analysis stage, the differences are most pronounced. Not only is the distinction one of specificity of the analysis phase (e.g., grounded theory most specific, narrative research less defined) but the number of steps to be undertaken can vary (e.g., extensive steps in phenomenology, fewer steps in ethnography)". Ethnographic research is a qualitative research about exploring the shared culture of a group of people where the focus is on a specific aspect of a cultural group and setting (Creswell, 2015) and not a broad aspect of the culture sharing group. These strengths are well suited for novice researchers. 
Finally, the term strengths and weakness could also be subjective as Gobo and Molle (2017) illustrated this perspective with the saying "two ethnographers, three different ways to do ethnography" (Gobo \& Molle, 2017: 17). Ethnography as methodology permits the use of qualitative research or quantitative research or mixed method, ethnography as a method is exclusively observations (Gobo \& Molle, 2017). While Yanik (2017) considers ethnographic studies as an ethnographer's researcher position of three stages with various experiences (initial, activation, acceptance), Yanik (2017) interpreted other ethnographers differently. Michelle Byrne's and Amy Zaharlick's "ethnographic studies are based on social relationships, a learning researcher, and first-hand natural observations over long periods of time" (Yanik, 2017: 116). Robert M. Emerson's, Rachel I. Fretz's and Linda L. Shaw's ethnographic studies are based on sharing their experiences (Yanik, 2017). Martyn Hammersley's and Paul Atkinson's proposed a guide listing "formulating research questions, deciding whom to observe, gaining access, establishing rapport, choosing a field role, dealing with informants, recording observations and conducting ethnographic interviews" (Yanik, 2017: 116), much similar to Karen O'Reilly and D.M. Fetterman. Far too many to review here, though of importance Abdullah (2019) subscribed to Erickson's (2010) perspective on classroom ethnography as making the familiar strange whereas general ethnography seeks to make the strange familiar.

\section{Rigor in Qualitative Research}

Finally, in any research, the question of rigor is essential in order to render the research transferable to other similar setting. In order to maintain ethnographic quality, Altheide and Johnson (1998) postulated four general criteria: plausibility, credibility, relevance, and importance of the topic. Nevertheless, we wish to point out that rigor in qualitative research in general comprised of four criteria: credibility, transferability, dependability, and confirmability (Ahmed \& Muhammad, 2018; Denzin \& Lincoln, 2000). For Hess (2001), the quality of an ethnography of science and technology is assessed through exposure and triangulation. Hess' (2001) list of exposure and triangulation were extensive. Important examples from the list include attending conferences, working in laboratories and schools, reading a vast technical literature, working in archives, developing long-term relationships with informants, interviewing outsiders and laypeople (Hess, 2001: 239). Hence, these were some of the possible ways to maintain quality Hess (2001).

We conclude this discourse that the greatest challenge of research "in the field of education is often connected to particular ways of wanting to improve schools/education/societies" (Gordon et al., 2001: 199). However, an interpretive approach is first needed as a way to understand such a fast - changing field particularly in science education (Gordon et al., 2001). Subsequently, critical approaches could be recommended. "Critical approaches are interested in making connections between research and practice, and want to combine theory with radical pedagogy" (Gordon et al., 2001: 199).

Due to the history of ethnography, one in Britain and one in America, it is safe to say that developing countries whose scholars opt to study in these respective countries will return to their homeland with qualitative ethnographic perspectives mirroring perspectives of the country in which they studied. Thus in Malaysia, where the pool of researchers are from Britain due to its colonial history, the majority of qualitative researchers would be trained with a British background. More studies would be needed to confirm this claim. 


\section{Classroom Ethnography}

In making school ethnography explicit, we now present some insights into what classroom ethnography is about. Classroom ethnography was developed in the early 1970's. It has certain family resemblances to general ethnography but it does not correspond exactly to the classical methods and content of general ethnography (Erickson, 2010). "Classroom ethnography portrays a topic-focused account of some aspect of a particular institutional setting in which none of the participants live their entire lives, with research typically being done by someone who, if not exactly an insider, still knows much about the setting, including knowledge that comes from prior life experience in similar settings" (Erickson, 2010: 322).

Watson-Gegeo (1997) argued, to study culture and the moment-by-moment classroom interaction using quantitative and/or experimental research designs is not appropriate. WatsonGegeo (1997) defined classroom ethnography as the study of the sociocultural nature of teaching and learning processes in school classrooms. It offered a holistic analysis pertaining to interactions in the classroom, and it also incorporated the informants' perspectives on their own behavior. Watson-Gegeo (1997) added, the approach to classroom ethnography ranged from purely naturalistic to partly statistical. Gordon et al. (2001) have also mentioned this possibility of ethnography having a quantitative flavour.

Erickson (2010: 322) postulated "In middle school, high school, and college classrooms, where only one subject is taught and the students meet as a class for a single instructional period and then move on to other classrooms, the analogy with daily life in a small community such as a village is more loose, and it may be less appropriate to consider such classrooms as settings for study that is ethnographic in spirit. Still there could be a family resemblance with ethnography in such settings". In order to do classroom ethnography, Erickson (2010) recommended 1) the hidden curriculum that accompanied subject matter instruction should be included in studies of the formal subject matter being taught; 2) the social identity categories are multidimensional and in dynamic ecological relationship when studying relations between the teacher(s) and students; 3) to make the familiar strange and visible, repeated visits are necessary across substantial strips of time as the researcher requires repeated learning attempts in order to answer questions of the actual full range of different ways of being a student in a particular classroom.

In studying ethnography, the duration of study might vary according to researchers. And as classroom ethnography's family resemblance to ethnography thus the duration too varies. Fetterman (2010) suggested, any classical ethnography would require the researcher to be in the field from 6 months to 2 years beginning with a survey period to learn the basics that was gathering information, gathering historical data, connecting with the informants and site, and for the months to come a gathering of information on the basic structure and function of the site. O'Reilly (2009: 5) postulated that "ethnography research properly begins once one has entered the field. This involves gaining access to the people and places being studied".

Watson-Gegeo (1997) recommended that the duration of the intensive, detailed observation of a classroom supplemented by interviews with teacher and students could be a semester or a year. Erickson (2010: 323) postulated "repeated visits across substantial strips of time" to make the familiar strange. It provides answers to the question "What is the actual full range of different ways of being a student in this particular classroom?” (Erickson, 2010: 323).

In Wang's (2016) qualitative research she conducted her classroom ethnography for the duration of one semester course in which she observed about 8 hours as a participant observer 
joining in her selected group's discussions; Steele's (2001) qualitative research used sociocultural theory to conduct her participant observation of $41 / 2$ months observing every mathematics session of her selected teacher and understanding the mathematical culture of her fourth grade (about 9 years old) students.

In Mariya's (2012: 60) multi-sited qualitative ethnographic study which included classroom observations, she wrote "I watched these classrooms over the nine month period for about three to four hours each week. I observed for 35 minutes each session, and observations and fieldnotes were taken for each lesson". In Raktham's (2008: 37) qualitative ethnographic study, her classroom observations were as she wrote "I planned to spend four weeks following the classroom".

In contrast, there is a risk of going native when spending more than six months with youths (O'Reilly, 2009). In Tickle's (2017: 10) qualitative research, she elaborated "by spending six months in the youth organisations in each of the fieldwork sites, a potential risk of what has been commonly termed as 'going native' (O'Reilly, 2009: 87)" could occur. Going native means "the danger for ethnographers to become too involved in the community under study, thus losing objectivity and distance" (O'Reilly, 2009: 87). Therefore, ethnographers are advised to practice the etiquette of leaving the filed meaning: "inform people of your plans ahead of time and try to avoid leaving or appearing to leave abruptly; explain why and where you are going; say your goodbyes personally; promise to keep in touch; where appropriate, keep in touch (Lofland \& Lofland, 1995: 63).

\section{Conclusion}

The contribution to the body of knowledge is subjective to the qualitative researcher. Ethnography does not always mean "the same to all social scientists at all times or under all circumstances. Clearly, there have been and will continue to be differences" (Atkinson et al., 2001: 5), the conduct of ethnography is open to non-English-speaking academics and crossdisciplinary thus contributions from different continents make up the growing contemporary ethnographic body of knowledge (Atkinson et al., 2001). Atkinson et al. (2001: 6) recognize that ethnographic research "means different things in different intellectual fields, disciplines or national context...It is all too easy to get caught up in the methodological or epistemological strife and to lose sight of the abiding commitment to the principled exploration and reconstruction of social worlds, our engagement with our fellow men and women, our commitment to the interpretation of local and situated cultures." Nevertheless, the aim of this article is to open up new research directions in research methodologies for potential local postgraduates.

\section{Reference}

Abdullah, A. (2019). The Culture of Learning Science in a Sabah Islamic Religious Secondary School Science Classroom. (PhD), University Malaysia Sabah, Sabah, Malaysia.

Ahmed, A., \& Muhammad, M. (2018). Rigour in Qualitative Research: Is There a Panacea to it? The Malaysian Journal of Qualitative Research, 4(1), 60-68.

Altheide, D. L., \& Johnson, J. M. (1998). Criteria for Assessing Interpretive Validity in Qualitatve Research. In N. K. Denzin \& Y. S. Lincoln (Eds.), Collecting and Interpreting Qualitative Materials (pp. 283-312). Thousand Oaks: SAGE.

Atkinson, P., Coffey, A., Delamont, S., Lofland, J., \& Lofland, L. (2001). Editorial Introduction. In P. Atkinson, A. Coffey, S. Delamont, J. Lofland, \& L. Lofland (Eds.), Handbook of ethnography (pp. 1-507). London: SAGE. 
Creswell, J. W. (2015). Educational Research: Planning, Conducting and Evaluating Quantitative and Qualitative Research (5th ed.). Boston, USA: Pearson.

Creswell, J. W., \& Poth, C. N. (2018). Five Qualitative Approaches to Inquiry: Comparing the Five approaches Qualitative Inquiry and Research Design: Choosing Among Five Approaches (4th ed., pp. 65-110). Los Angeles: SAGE.

Delamont, S., \& Atkinson, P. (1980). The Two Traditions in Educational Ethnography: Sociology and Anthropology Compared. British Journal of Sociology of Education, 1(2), 139-152.

Delamont, S., \& Atkinson, P. (1995). Fighting Familiarity: Essay on Education and Ethnography. Cresskill, NJ: Hampton Press.

Denzin, N. K., \& Lincoln, Y. (2018). The SAGE Handbook of Tourism and Management. Thousand Oaks, CA: SAGE.

Denzin, N. K., \& Lincoln, Y. S. (2000). Introduction: The Discipline and Practice of Qualitative Research. In N. K. Denzin \& Y. S. Lincoln (Eds.), Handbook of Qualitative Research (2 ed., pp. 1-28). Thousand Oaks, CA: SAGE.

Denzin, N. K., \& Lincoln, Y. S. (2000a). Paradigms and Perspectives in Transition. In N. K. Denzin \& Y. S. Lincoln (Eds.), Handbook of Qualitative Research (2 ed., pp. 157-162). Thousand Oaks, CA: SAGE.

Denzin, N. K., \& Lincoln, Y. S. (Eds.). (1994). The Handbook of Qualitative Research. . Thousand Oaks, CA: SAGE.

Erickson, F. (2010). Classroom Ethnography. California: Elsevier.

Fetterman, D. M. (2010). Ethnography: Step-by-Step (3rd ed.). Thousand Oaks: SAGE.

Gobo, G., \& Molle, A. (2017). Doing Ethnography (2 ed.). London: SAGE.

Gordon, T., Holland, J., \& Lahelma, E. (2001). Ethnographic Research in Educational Settings. In P. Atkinson, A. Coffey, S. Delamont, J. Lofland, \& L. Lofland (Eds.), Handbook of ethnography (pp. 188-203). London: SAGE.

Gray, D. E. (2013). Doing Research in the Real World. London: SAGE.

Hess, D. (2001). Ethnography and the Development of Science and Technology Studies. In P. Atkinson, A. Coffey, S. Delamont, J. Lofland, \& L. Lofland (Eds.), Handbook of ethnography (pp. 234-245). London: SAGE.

Lofland, J., \& Lofland, L. (1995). Analyzing Social Settings: A guide to Qualitative Observation and Analysis. California: Wadsworth Publishing Company.

Mariya, M. (2012). 'I Don't Learn at School, So I Take Tuition' An Ethnographic Study of Classroom Practices and Private Tuition Settings in the Maldives. (PhD), Massey University New Zealand.

O'Reilly, K. (2009). Key Concepts in Ethnography. Los Angeles: SAGE.

O'Reilly, M., \& Parker, N. (2013). 'Unsatisfactory Saturation': A Critical Exploration of the Notion of Saturated Sample Sizes in Qualitative Research. Qualitative Research, 13(2), 190-197.

Raktham, C. (2008). Cultures and Learner Behaviours: A Qualitative Investigation of a Thai Classroom. (PhD), University of Warwick, UK.

Steele, D. F. (2001). Using Sociocultural Theory to Teach Mathematics: A Vygotskian Perspective. School Science and Mathematics, 101(8), 404-416.

Tickle, S. (2017). Ethnographic Research with Young People: Methods and Rapport. Qualitative Research Journal, 17(2), 66-76.

Vidich, A. J., \& Lyman, S. M. (2000). Qualitative Methods: Their History in Sociology and Anthropology. In N. K. Denzin \& Y. S. Lincoln (Eds.), Handbook of Qualitative Research (2 ed., pp. 37-84). Thousand Oaks: SAGE. 
Wang, C. (2016). Why Are My Chinese Students So Quiet?: A Classroom Ethnographic Study of Chinese Students' Peer Review Activities in an American Multilingual Writing Class. INTESOL Journal, 13(1).

Watson-Gegeo, K. A. (1997). Classroom Ethnography. In N. H. Hornberger \& D. Corson (Eds.), Encyclopedia of Language and Education (Vol. 8, pp. 135-144). USA: Kluwer Academic Publishers.

Yanik, B. (2017). An Ethnographic Approach to Education: What Are You Doing in This Village? Journal of Education and Practice, 8(26), 113-118. 